\title{
Ecosystem Services from Forest Management Units in Eastern and Central Bhutan
}

Jigme Wangchuk

Kinley Choden

Robin R. Sears

Himlal Baral


Working Paper 248

\title{
Ecosystem Services from Forest Management Units in Eastern and Central Bhutan
}

\author{
Jigme Wangchuk \\ Ugyen Wangchuck Institute for Conservation and Environmental Research (UWICER) \\ Kinley Choden \\ Ugyen Wangchuck Institute for Conservation and Environmental Research (UWICER) \\ Robin R. Sears \\ Harvard Forest, Harvard University \\ Center for International Forestry Research (CIFOR) \\ Himlal Baral \\ Center for International Forestry Research (CIFOR)
}


Working Paper 248

(c) 2019 Center for International Forestry Research

(c) (i) Content in this publication is licensed under a Creative Commons Attribution 4.0 International (CC BY 4.0), http://creativecommons.org/licenses/by/4.0/

DOI: 10.17528/cifor/007327

Wangchuk J, Choden K, Sears RR and Baral H. 2019. Ecosystem Services from Forest Management Units in Eastern and Central Bhutan. Working Paper 248. Bogor, Indonesia: CIFOR.

\section{CIFOR}

Jl. CIFOR, Situ Gede

Bogor Barat 16115

Indonesia

$\mathrm{T}+62(251) 8622-622$

F +62 (251) 8622-100

E cifor@cgiar.org

\section{cifor.org}

We would like to thank all funding partners who supported this research through their contributions to the CGIAR Fund. For a full list of the 'CGIAR Fund' funding partners please see: http://www.cgiar.org/our-funders/

Any views expressed in this publication are those of the authors. They do not necessarily represent the views of CIFOR, the editors, the authors' institutions, the financial sponsors or the reviewers. 


\section{Contents}

Acknowledgements $\quad$ v

1 Introduction 1

1.1 Forest ecosystem services 1

1.2 Forestry in Bhutan 2

1.3 FMU in the local context 2

2 Methods $\quad 4$

2.1 Study area 4

2.2 Study design and tools $\quad 5$

3 Results $\quad 6$

3.1 Priority forest ecosystem services 6

3.2 Trends in the provision of ecosystem services from FMUs 8

4 Discussion $\quad 10$

5 Conclusions 11

$\begin{array}{ll}\text { References } & 12\end{array}$

$\begin{array}{ll}\text { Appendix } & 15\end{array}$ 


\section{List of figures and tables}

\section{Figures}

1 Recently logged area in Khaling-Kharungla FMU, Trashigang. 3

2 Location of the five study areas in central and eastern Bhutan. 5

3 Frequency of priority ecosystem services.

4 Timber lot rot at the depot, Umlingbadep, Rongmanchhu FMU. 9

\section{Tables}

1 General information on FMUs. Villages in bold letters were included in this project.

2 Priority ranking of importance of ecosystem service by village and gender in FGD.

3 Perceived trends in the provision of prioritized ecosystem services from FMU forests. 


\section{Acknowledgements}

The people's perception study on ecosystem services in FMU was supported by the SLANT Bhutan project, a collaborative research project between UWICER and CIFOR, with funding assistance from the people of Austria. The authors would like to thank the participants from all the villages, who gave their best to present their perceptions of the importance of the local forest. We are also grateful to the participants at the respective FMUs and the people in charge of management of the territorial divisions, Mongar, Trashigang, and Zhemgang for delegating the respective FMUs in-charge for facilitating the FDG successfully in their locality.

Jamyang Tenzin, currently at Global Tiger Center, Gelephu, and Karma Wangdi from UWICER were instrumental in assisting in the field works and co-moderating during the FDG. We would like to thank them for their selfless contribution. 


\section{Introduction}

\subsection{Forest ecosystem services}

The benefits that humans obtain from forests are vitally important for rural livelihood in the Himalaya (Bhatta et al., 2015). Forested ecosystems and natural rivers and wetlands are particularly critical in mountain regions that receive high amounts of precipitation, such as in eastern Himalaya, since forests serve to moderate the overland flow of precipitation and snow melt (Bathurst et al., 2011). The presence of forest does not prevent flooding downstream per se, as forest soils will saturate rapidly with heavy rainfall, but they help in moderate rainfall and snowmelt as the trees take up and release much of the soil water through evapotranspiration (FAO and CIFOR, 2005; Gilmour, 2014). Clearcutting a forest may cause a temporary increase in stream flow, stream sediment load and nutrient load, vegetation regrowth can re-stabilize the soil and nutrient flow in three to six years (Brown et al., 1973). Permanent conversion of forest to grassland or other non-forest cover may result in permanent increase in total water runoff in a watershed (FAO and CIFOR, 2005).

Forests provide an array of other benefits and meanings. People gather non-timber forest goods from nearby forests, such as wild-collected food and fuel wood, which may be difficult to import from elsewhere given the cost and difficulties in movement and transportation in mountain topography. Forests hold aesthetic and cultural meaning to residents, leading to the development of moral responsibilities toward nature (Cooper et al., 2016). Research and popular notions agree that forests provide critical regulating services in mountain landscape in eastern Himalaya (Måren et al., 2014; Rinzin et al., 2009). Forests filter particulate matter from air pollution (Terzaghi et al., 2013), and they generate and regulate micro-climates, including in streams (Dan Moore et al., 2005), maintaining both warmer and cooler understory air and soil, depending on the season (Chen et al., 1999).

These and other ecosystem services directly and indirectly contribute to human well-being at multiple scales. For this reason, it is vital to maintain forest cover. At the same time, changing consumption patterns and local and global market shifts increase demand on forest resources, imperiling the integrity of forests from local to global scales (Paudyal et al., 2016). These demands drive forest degradation and its conversion to developed land for housing, roads and other infrastructure required to serve society

In Bhutan, evidence of links between forest provisioning services, such as timber, fuel wood and non-wood forest products (NWFP), and rural livelihoods have been shown (Sears et al., 2017). There is still much work to do to quantify ecosystem services, especially in mountain regions (Baral et al., 2017), much less put a price tag on them. Preliminary analysis of ecosystem services in Bhutan suggests that the estimated value of natural services is $15.5 \$$ billion per year, out of which $93.8 \%$ (14.5 $\$$ billion/year) of the total value is contributed by forests (Kubiszewski et al., 2013). Processes to assess the values of ecosystem services are in the early stages in Bhutan. Studies have taken an approach using modeling software tools developed for quantifying specific ecosystem services. The InVEST tool was used to estimate the value of sediment retention services at the sub-watershed level (WWF, 2017). Another assessment using the TEEB model helped to estimate the economic value of watershed management practices—specifically maintaining or restoring forest cover-for maintaining hydroelectric stations (UWICER, 2018).

The constraints on these modeling exercises include a lack of fine-scale data on the ecological processes from the ecosystems in question. Rectifying that situation requires long-term monitoring systems for ecosystem components and processes of concern, including hydro-meteorological stations, 
weirs, and periodic biodiversity assessments. Such infrastructure and processes carry high costs, which many communities and nations cannot assume.

In the absence of biophysical data that monitoring systems would provide, the relative importance of ecosystem services at the local scale can be assessed through qualitative research approaches (Baral et al., 2017; Scholte et al., 2015). Through participatory rural appraisal methods, centered on place-based analysis, the perceptions, beliefs and understandings of local residents may be identified and compared across political districts and ecosystems (Brown, 2013). These processes can also help to identify the needs and priorities of local people for conservation and management of these ecosystems.

In this paper, we report on the ecosystem services from the state natural forests under scientific forestry management plans as perceived by local residents.

\subsection{Forestry in Bhutan}

Modern principles of scientific forest management were introduced in Bhutan in 1952 to help ensure continued production of the essential timber resource base for this developing and then quite isolated country. By 1965 forest management was centralized with preparation of forest management plans under the Department of Forestry in the Ministry of Trade and Industry. The state logging program was formally commercialized in 1984, operating in designated forest management units (FMU) of government reserve forests (Webb and Dorji, 2016).

Forest management in the FMUs in Bhutan is based on principles of sustained timber yield while minimizing environmental damage and aspires to achieve multiple objectives that reflect the needs of Bhutanese society. The management plans consider both the timber stock and environmental sensitivity across the forest management unit. The employment of best practices in logging has shown to control impacts of tree removal operations on water quality in the local watershed (Brown et al., 1973; Corbett et al., 1978; Martin and Hornbeck, 1994). Depending on the forest cover type and topography, harvest in the forest management area may fall under five silviculture systems: selection and improvement, group selection for conifer, clear felling and planting, fir management system, and seed tree system.

By 2018, there were 20 formal forest management units (FMUs) in state forests designated across the country, comprising some 193,822 ha, catering to both commercial and rural subsistence needs. The total annual allowable cut (AAC) in the FMUs in 2017 was 123,095 cubic meters with a net operable area of 63,684 ha (DoFPS, 2018). A further 83,215 ha of forestland is designated for local governance under the Community Forest Program (DoFPS, 2018). These community forests area also managed under scientific forestry practices, but decisions are made by local management group rather than by central forestry office.

Upon designating the FMU, an assessment is made by foresters of the standing stock and projected volume increments. Little consideration is given during the planning phase to other forest goods and services from the areas, such as stocks of non-wood forest products (NWFP), water regulation, or aesthetic values. Although there are studies in Bhutan on the outcomes of different silvicultural systems on the forest structure and composition of different forests (Buffum et al., 2008; Covey et al., 2015; Moktan et al., 2009), there has been little study of how silvicultural operations impact the broader ecosystems and the suite of ecosystem services in the locality.

\subsection{FMU in the local context}

Rural communities are located within and nearby to many of the FMUs, having existed prior to the designation of the FMU. Residents of these villages have relied on nearby forest and water 
resources since time immemorial to meet their subsistence needs for fuel, food, shelter, and spiritual practice. The designation of the FMU did not change their needs, and in recognition of that, the Royal Government allows the continued use of forests resources within the FMU by local residents. Thus, local residents continue to rely on FMU areas for the goods and services, which are vital for rural livelihood.

The increasing population in Bhutan, coupled with economic growth and new construction in urban centers, result in increasing pressure on the timber stocks in the FMUs, posing a threat to the sustainability of the resource base. In addition, in some FMUs, a substantial volume of felled timber have remained staked for years and deteriorated in quality and quantity as the timber could not be sold because of inferior quality and improper disposal plan and extraction (Wangdi, 2018). The decline of mature trees for timber can lead to a deterioration of cascading ecosystem services. At the same time, natural regeneration, especially in broadleaf forests, can be depressed by excessive livestock grazing in the forests (Darabant et al., 2007; Rai et al., 2014). A lack of research on how forest management operations affect the structure and function of these forests, and therefore the ecosystem services, makes it difficult to assess the sustainability of the management plan implementation (Stark, 2002).

These pressures and threats add up to some uncertainty about the sustainability of current FMU management systems and forestry operations. Work must be done to assess past and current forestry planning, operations and governance in government reserve forests, and changes should be made if necessary to correct the course. As a first step, we set out to identify the suite of ecosystem services that communities recognize from the FMU areas and their perceptions of changes to the forest over time. The aim of our study was to understand the local benefits these managed forests provide to local residents for their livelihood and to ascertain through their perceptions whether current forestry practices and other forest uses in the FMU support the continued provision of key forest ecosystems services there.

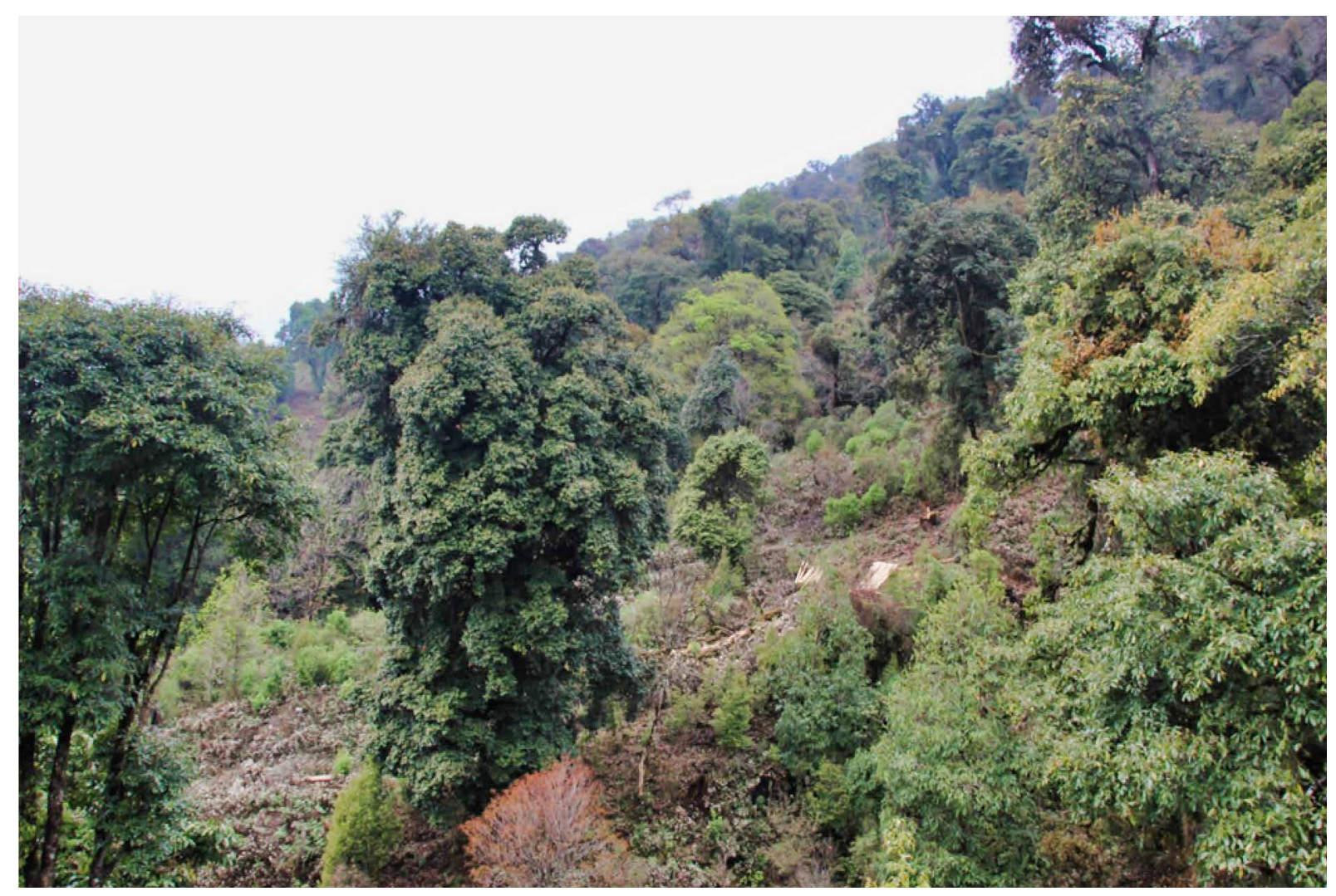

Figure 1. Recently logged area in Khaling-Kharungla FMU, Trashigang.

Photo: Jigme Wangchuk 


\section{Methods}

\subsection{Study area}

Five forest management units (FMU) were selected in the mid hills of central and eastern Bhutan (Table 1; Fig.1) based on their proximity to villages and local residents' dependence on the forest resources within the FMU, especially drinking water resources. The FMUs range from 2400 to over 10,000 hectares in area and are all in their second or third management phase (Table 1). One of the areas, Kekhar, is not technically an FMU; rather it is government reserve forest area designated as a "working scheme," which is an ad hoc FMU allocated to help meet the increase in demand for timber.

Table 1. General information on FMUs. Villages in bold letters were included in this project.

\begin{tabular}{|c|c|c|c|c|c|c|c|c|c|}
\hline \multirow[t]{2}{*}{ District } & \multirow{2}{*}{$\begin{array}{l}\text { Name of } \\
\text { FMU/ } \\
\text { Working } \\
\text { Scheme }\end{array}$} & \multirow[t]{2}{*}{$\begin{array}{c}\text { Year } \\
\text { established }\end{array}$} & \multirow[t]{2}{*}{ Plan phase } & \multirow{2}{*}{$\begin{array}{l}\text { Total } \\
\text { FMU } \\
\text { area } \\
\text { (ha) }\end{array}$} & \multirow[t]{2}{*}{$\begin{array}{l}\text { Altitude } \\
\text { range }\end{array}$} & \multirow[t]{2}{*}{$\begin{array}{l}\text { Predominant } \\
\text { forest type }\end{array}$} & \multicolumn{3}{|c|}{$\begin{array}{c}\text { Villages and numbers of } \\
\text { households (HH) associated with } \\
\text { the FMU }\end{array}$} \\
\hline & & & & & & & Village name & $\begin{array}{l}\mathrm{HH} \text { in } \\
\mathrm{FMU}\end{array}$ & $\begin{array}{c}\text { HH } \\
\text { outside } \\
\text { FMU }\end{array}$ \\
\hline Mongar & Lingmethang & 1996 & $\begin{array}{l}\text { 2nd Plan } \\
\text { 2008-2017 }\end{array}$ & 10,570 & $\begin{array}{l}640- \\
3321\end{array}$ & $\begin{array}{l}\text { Broadleaf, } \\
\text { chir pine }\end{array}$ & $\begin{array}{l}\text { Brogsar } \\
\text { Kalapang } \\
\text { Masangdaza } \\
\text { Mangling } \\
\text { Tangsibe } \\
\text { Jangdung }\end{array}$ & 76 & 30 \\
\hline Trashigang & $\begin{array}{l}\text { Khaling- } \\
\text { Kharungla }\end{array}$ & 1995 & $\begin{array}{l}\text { 2nd Plan } \\
\text { 2009-2019 }\end{array}$ & 7,265 & $\begin{array}{l}1120- \\
3880\end{array}$ & Broadleaf & $\begin{array}{l}\text { Kurichilo } \\
\text { Brekha } \\
\text { Kharphu } \\
\text { Bephuthung }\end{array}$ & 289 & \\
\hline Lhuentse & Rongmanchhu & 2007 & $\begin{array}{l}\text { 2nd Plan } \\
\text { 2018-2028 }\end{array}$ & 6,401 & $965-3865$ & $\begin{array}{l}\text { Broadleaf, } \\
\text { mixed conifer }\end{array}$ & $\begin{array}{l}\text { Budur } \\
\text { Kupinesa } \\
\text { Wambur } \\
\text { Khablang } \\
\text { Goney } \\
\text { Lagay } \\
\text { Umling, } \\
\text { Bangtsho } \\
\text { Bumling } \\
\text { Gorgan }\end{array}$ & 181 & 202 \\
\hline Trongsa & Chendebji & 1996 & $\begin{array}{l}\text { 3rd Plan } \\
\text { 2018-2027 }\end{array}$ & 7853 & $\begin{array}{l}1640- \\
4100\end{array}$ & $\begin{array}{l}\text { Mixed conifer, } \\
\text { broadleaf }\end{array}$ & $\begin{array}{l}\text { Chendebji } \\
\text { Drangla } \\
\text { Nyala } \\
\text { Setta } \\
\text { Brogena }\end{array}$ & 87 & \\
\hline Zhemgang & $\begin{array}{l}\text { Kekhar } \\
\text { Working } \\
\text { Scheme }\end{array}$ & 2009 & $\begin{array}{l}\text { 3rd Plan } \\
2018-2022\end{array}$ & 2461 & $\begin{array}{l}1976- \\
2888\end{array}$ & Broadleaf & Kekhar & & 56 \\
\hline
\end{tabular}




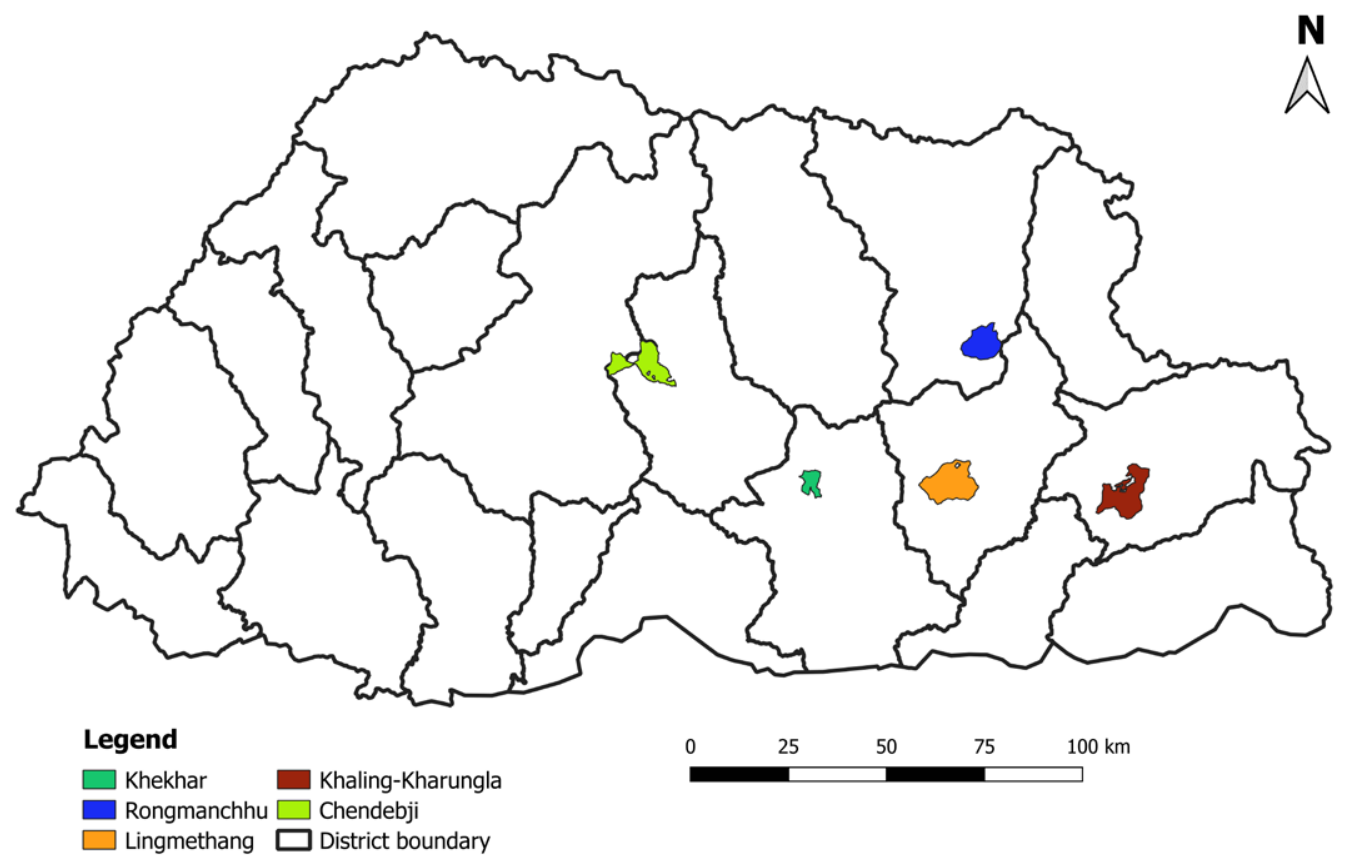

Figure 2. Location of the five study areas in central and eastern Bhutan.

In all but Kekhar, multiple villages were associated with, and even located within, the FMU. Four FMU areas were dominated by broadleaf forest.

\subsection{Study design and tools}

We conducted a social survey using focus group discussion (FGD) adapted from (Morgan, 1997) and interviews with communities to understand the local people's perceptions of and dependencies on forest ecosystem services. Tools such as resource mapping, participatory rapid assessment (PRA), and photography were used to enhance the discussions. Villages inside and close to the FMU area were called to participate.

This research was conducted in eight villages, each associated with one of the five FMUs, between April 2017 and January 2018. One hundred people across all FMUs participated; they were primarily farmers, with a few students, one village head man (Tshogpa) and a monk. We ran a total of 10 group discussions in the eight villages. The groups were segregated by gender, each with 10 participants and irrespective of age and occupation. The results are subjective, since they represent the perceptions and understandings through the practical experiences about the services they obtain from their landscape, rather than direct measures.

To initiate the discussions, participants were asked to list all the ways they benefit from the FMU forest areas. After this initial discussion, the moderator prompted participants to think of other ways the forest is or might be useful, perhaps even indirectly. Then respondents were requested to identify the five most important services, irrespective of their major category. Groups then identified and prioritized the top five services after vigorous discussion and consensus based on their relative contribution to household livelihood and well-being of the community. They were asked for a justification of the prioritization and definition of the change in availability for the top five services between 2006 to 2016. Finally, groups were asked to share ideas on measures to improve the services in the future. 


\section{Results}

\subsection{Priority forest ecosystem services}

The communities within or neighboring to FMU areas acquire a wide range of goods and services from these forests. Across all focus groups, ten services were identified as the priority benefits gained from the FMU forest areas. This reported list is not exhaustive of all the perceived benefits from these forests. This list includes three provisioning services (timber, freshwater, stone for building materials); four regulating services (fresh air, carbon sequestration, pollination, local weather regulation); two cultural services (spiritual and religious value, birth and guardian deity); and one supporting service (land productivity) (Table 2). The raw data are provided in the appendix.

In no instance were all ten focus groups in total agreement about the list or prioritization of services, but nine out of ten groups gave land productivity the highest priority (Table 2, Figure 3). Timber and fresh water provision were split between second and third priorities almost equally. Fresh air from forests largely occupied fourth place, while stone was assessed in fifth place by six groups. Five

Table 2. Priority ranking of importance of ecosystem service by village and gender in FGD. (F- Female focus group, M-Male focus group; first and second ranks in bold to highlight their high position)

\begin{tabular}{|c|c|c|c|c|c|c|c|c|c|c|}
\hline \multirow[t]{2}{*}{ Service } & \multicolumn{2}{|c|}{$\begin{array}{c}\text { Khaling Kharungla } \\
\text { FMU }\end{array}$} & \multicolumn{2}{|c|}{ Lingmethang FMU } & \multicolumn{2}{|c|}{$\begin{array}{l}\text { Rongmanchhu } \\
\text { FMU }\end{array}$} & \multicolumn{2}{|c|}{ Chendebji FMU } & \multicolumn{2}{|c|}{$\begin{array}{c}\text { Kekher Working } \\
\text { Scheme }\end{array}$} \\
\hline & $\mathrm{F}$ & $\mathbf{M}$ & $\mathrm{F}$ & M & $\mathrm{F}$ & M & F & $\mathbf{M}$ & F & $\mathbf{M}$ \\
\hline \multicolumn{11}{|l|}{$\begin{array}{l}\text { Supporting } \\
\text { services }\end{array}$} \\
\hline $\begin{array}{l}\text { Land } \\
\text { productivity }\end{array}$ & First & First & First & First & First & First & Second & First & First & First \\
\hline \multicolumn{11}{|l|}{$\begin{array}{l}\text { Provisioning } \\
\text { services }\end{array}$} \\
\hline Freshwater & Second & Third & Second & Second & Third & Third & Third & Second & Second & Second \\
\hline Timber & Third & Second & Third & Third & Second & Second & Fourth & Third & Third & Third \\
\hline Stone & Fifth & Fifth & - & Fifth & Fifth & Fifth & Fifth & & & \\
\hline \multicolumn{11}{|l|}{$\begin{array}{l}\text { Regulating } \\
\text { services }\end{array}$} \\
\hline Fresh air & Fourth & Fourth & Fourth & Fourth & Fourth & Fourth & First & & Fourth & Fourth \\
\hline $\begin{array}{l}\text { Carbon } \\
\text { sequestration }\end{array}$ & & & Fifth & & & & & & & \\
\hline Pollination & & & & & & & & & Fifth & \\
\hline $\begin{array}{l}\text { Local weather } \\
\text { regulation }\end{array}$ & & & & & & & & & & Fifth \\
\hline \multicolumn{11}{|l|}{$\begin{array}{l}\text { Cultural } \\
\text { services }\end{array}$} \\
\hline $\begin{array}{l}\text { Birth and } \\
\text { prosperity } \\
\text { deity }\end{array}$ & & & & & & & & Fifth & & \\
\hline Spiritual value & & & & & & & & Fourth & & \\
\hline
\end{tabular}




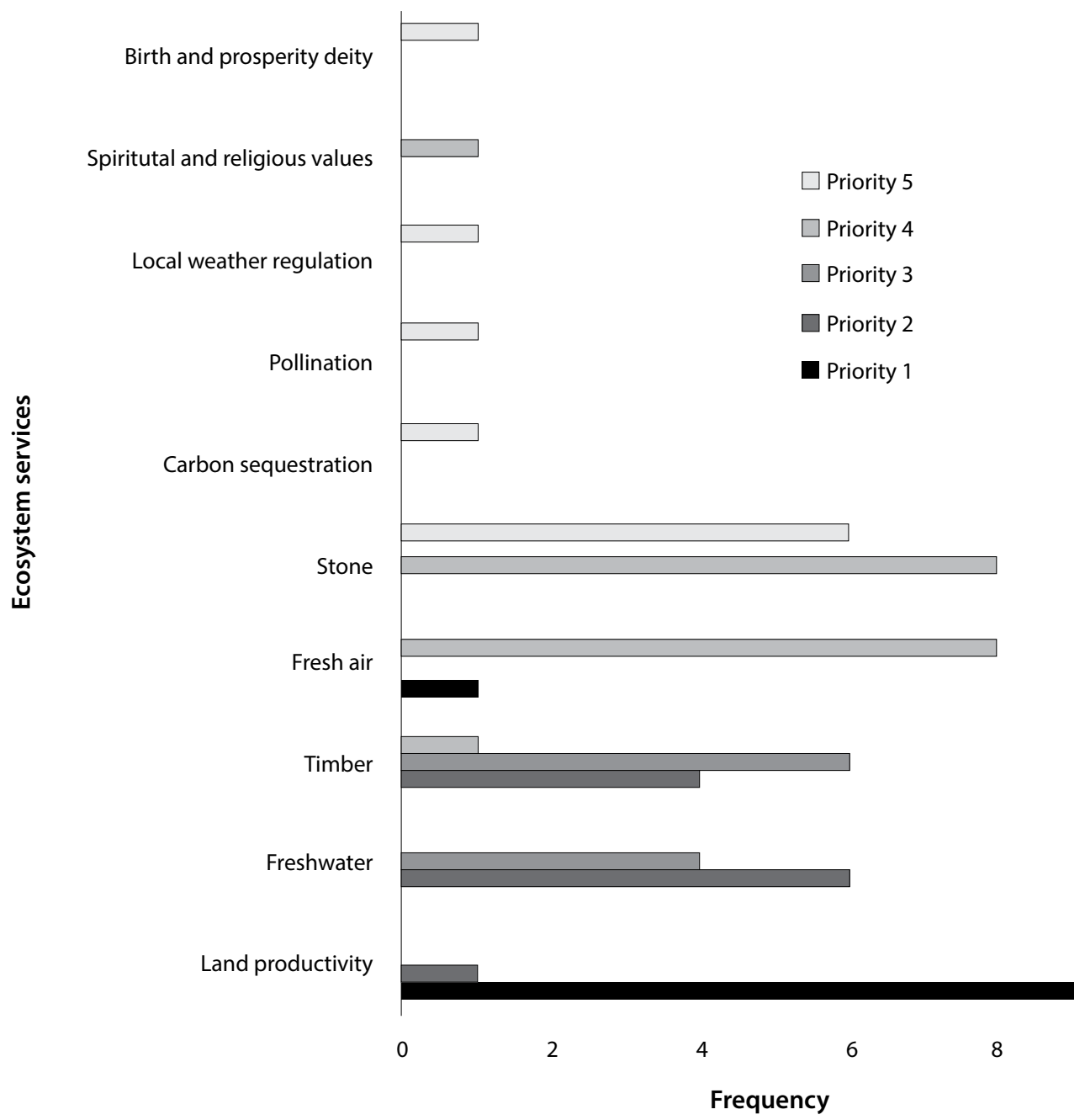

Figure 3. Frequency of priority ecosystem services.

services were mentioned by only once: regulating services of pollination and carbon sequestration and local weather regulation, and cultural services of spiritual and religious, and birth and prosperity deity.

The priority given by different communities and by gender differs slightly based on their background, interest, knowledge and experiences obtained from their livelihood activities. Male groups showed some preference for spiritual and religious values for maintaining peace and prosperity, while female groups demonstrated a preference for carbon sequestration and pollination for maintaining a clean environment and genetic continuity.

Communities residing near to and in the FMUs use timber for house construction and water for drinking and irrigation. Stone is used for house construction and wall fencing to protect crops from wild animals and for terracing fields for soil stabilization. Amongst all of the services prioritized by the focus groups, land productivity is the base and foundation, as local people consider land as the main source of other ecosystem services, including the cultivation of crops, source of water, timber, stone, leaf litter, fodder, and other forest resources. Both genders across all FMUs, but for one group of women, identified land productivity as the first priority.

Reasons for prioritization by the members across the FMUs and by gender appear to be similar, with no clear differences in justification. 
In only one FMU, Rongmanchhu, did both male and female groups agree perfectly across the five prioritized services. Similarly, both the male and female groups from Lingmethang had the same priority except for the fifth, which the female group identified as carbon sequestration while male group had stone. The groups at Khaling-Kharungla FMU identified the same ecosystem services but the genders ranked them slightly differently. For the male group, timber was ranked second, for its utility for construction, fuel wood, and carbon sequestration, while the female group felt that freshwater is crucial to trees for timber. Indeed, six of the ten groups placed freshwater as the second priority as it is regarded as fundamental to well-being for drinking, health and hygiene growth of forests, animals and production of agricultural crops.

Eight groups ranked fresh air fourth. As per the respondents, fresh air is crucial for health, growth and absorbs carbon for the well-being of living organisms on earth. Stone was ranked fifth by six groups. Participants stated that stone plays an important role as it forms the basis for soil formation, and stones are used for construction, soil management and fencing for crops. Group felt that stone is abundant, so it was ranked low out of the top five, but the fact that it made the list at all belies its overall importance to the livelihoods of rural residents. The female group that prioritized carbon sequestration in fifth place suggested that increasing anthropogenic activities has added carbon to the atmosphere, which deters the health of ecosystem on earth. The male group from Chendebji was the only one to rank cultural services of forests being where birth and guardian deities reside and for their general spiritual value. The deity that gives swift birth and prosperity in their life was felt to be crucial for the wellbeing of the community and the sustained provision of ecosystem services overall.

\subsection{Trends in the provision of ecosystem services from FMUs}

With two exceptions, all groups perceived a decline in the top five ecosystem services from FMU forests over the past decade (2006-2016) (Table 3). The two cultural services were perceived by the same single focus group to have increased. Fresh water provision and land productivity were perceived to increase or stay the same by two separate women's groups.

The pertinent issues raised by the groups as causing the decline in forest services included increasing population, pollution, road construction, higher demand for timber resources, waste disposal, increasing machine and vehicles, deforestation and climate change. Another reason they gave for the decline was over-exploitation of resources by both residents and outsiders intruding in the FMU.

The pertinent issue raised by the community associated with the Rongmanchhu FMU was mainly attributed to the under-utilization of harvested timber at the depot. One member of the male group there said this: "NRDCL has harvested the timber and let it rot in the depot, which not only led to the substantial loss of income but also deteriorated ecosystem services in terms of timber supply and soil stability in the forest." (Figure 4).

Following the comments of the participants, the site was visited by the research group where we found many lots of decaying timber that have been stacked for a few years. This timber otherwise could be used for construction. When asked, the depot manager stated two reasons for the lack of sale: the depot is located quite some distance from the highway, and the timber was of inferior quality.

The provision of fresh water was of serious concern to the male group from the Lingmethang FMU area, which suggested that there has been a dramatic decrease in the past decade. They attributed the decrease to the extraction of timber, construction of roads, and the installation of concrete at the source of the stream. 
Table 3. Perceived trends in the provision of prioritized ecosystem services from FMU forests (-- highly decreased, - decreased, 0 no change, + increased, ++ highly increased)

\begin{tabular}{|c|c|c|c|c|c|c|c|c|c|c|}
\hline \multirow[t]{3}{*}{ Ecosystem services } & \multicolumn{10}{|c|}{ Name of the Forest Management Units and group by gender } \\
\hline & \multicolumn{2}{|c|}{ Chendebji } & \multicolumn{2}{|c|}{ Kekhar } & \multicolumn{2}{|c|}{ Lingmethang } & \multicolumn{2}{|c|}{$\begin{array}{l}\text { Khaling- } \\
\text { Kharungla }\end{array}$} & \multicolumn{2}{|c|}{ Rongmanchhu } \\
\hline & Female & Male & Female & Male & Female & Male & Female & Male & Female & Male \\
\hline \multicolumn{11}{|c|}{ Habitat/Supporting services } \\
\hline Land productivity & - & - & - & - & ++ & + & - & - & 0 & - \\
\hline \multicolumn{11}{|c|}{ Provisioning services } \\
\hline Freshwater & ++ & - & - & - & - & -- & & - & - & - \\
\hline Timber & - & - & -- & - & - & - & & - & - & - \\
\hline Stone & - & & & & & - & & - & - & 0 \\
\hline \multicolumn{11}{|c|}{ Regulating services } \\
\hline Fresh air & - & & - & - & - & - & & - & - & - \\
\hline Carbon sequestration & & & & & - & & & & & \\
\hline Pollination & & & - & & & & & & & \\
\hline $\begin{array}{l}\text { Local weather } \\
\text { regulation }\end{array}$ & & & & - & & & & & & \\
\hline
\end{tabular}

\section{Cultural Services}

Spiritual and

religious value

Birth and guardian

deity

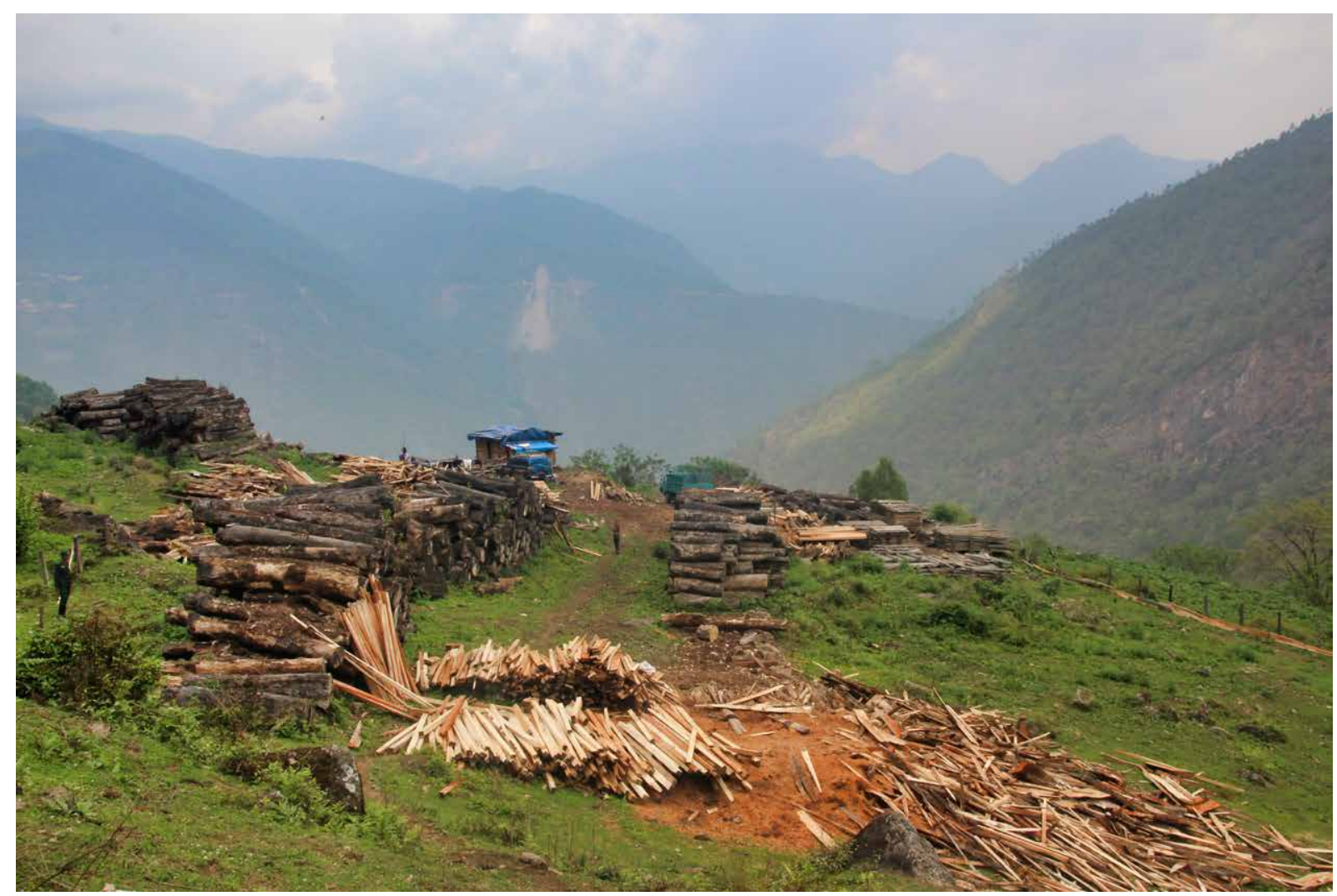

Figure 4. Timber lot rot at the depot, Umlingbadep, Rongmanchhu FMU. 


\section{Discussion}

We found that the whole suite of forest ecosystem services in general were not readily identified by local residents, who had particular difficulty in identifying regulatory and supporting services. This finding is supported from studies elsewhere (Sagie et al., 2013). Only after an explanation by a moderator on the definitions of regulating, supporting, and cultural services were groups able to identify a few services that belong to these categories. These services are also difficult to translate from technical terms to the local vernacular. After detailed explanation from the moderator, with examples cited, participants appeared to be aware of the services they obtain from the FMUs and how they are indispensable for their livelihood. This suggests a need to create awareness among the public to appreciate the gross value of ecosystem services.

Provisioning services were more readily identified overall by the focus groups, since people depend on things like timber directly for their livelihood. Regulating services are often not perceived by communities whose members are directly involved in the agriculture activities (Swinton et al., 2007). Our study indicated that FMU members with an educational background more commonly perceived regulating services, whereas communities who work in the farm land more easily perceived provisioning services.

Communities perceive and prioritize ecosystem services differently according to their geography (Iniguez-Gallardo et al., 2018). In our study, such perception and prioritization is largely influenced by the role the community plays in the FMU. For example, the men's group members from Chendebji were more concerned about conservation of spiritual and religious value, and birth and guardian deity, which are perceived to bring peace and harmony for the community. While the women's groups from Kekhar and Lingmethang prioritized pollination and carbon sequestration, respectively, for maintaining the sustained yield of crops and a clean environment. This indicates that perception of services depends on individuals, where they live and their relationship with resources they obtain from the forest (Zoderer et al., 2016). This study indicated that habitat or supporting services (land productivity) had high priority followed by provisioning, regulating and cultural services. Communities perceived land productivity as the primary foundation for all other ecosystem services and food production for living animals.

The forest management regimes practiced in the FMUs were perceived by villagers to imperil ecosystem services, particularly in the quality and quantity of timber production. Concerns about excessive harvest of timber are raised by the communities within the designated area under FMU. This concern is in line with reports that $22 \%$ of the forests within FMU areas experienced degradation of forest cover (Phuntsho, 2015; WMD, 2017). It should be noted that local residents may also receive timber from other forests through the Subsidized Rural Timber Scheme program if the local forests do not contain sufficient harvestable stock. The entitlements for the rural subsidized timber are not assessed within the scope of timber resource availability and sustainability at the site. For example, the natural regeneration in logged broadleaf forests depends proportionately on the number of grazers. With decreasing cattle grazing, naturally regeneration increases (Buffum et al., 2009). As such, grazing in the FMU is not restricted and local community members have rights to access the FMU as their grazing area. This is one of the drivers perceived by communities that has led to a decline of ecosystem services, despite whether the forest management was as planned and executed in accordance to the annual allowable cut. 


\section{Conclusions}

Forests represent the largest contribution to communities' livelihoods through direct and indirect provision of ecosystem services in the forest management unit areas. Provisioning and cultural services were readily recognized by villagers, while difficulty arose in recognizing the indirect services of habitat and ecological regulation. Forests also host aesthetic, religious and sacred sites, and people express close association between the forest and spiritual well-being. Ultimately, people believe that they are blessed by the spiritual elements of forests with multiple ecosystem services.

Scientific forest management in the FMUs based on the annual allowable cut was assumed by the state foresters to allow for sustained timber yield from the forest for both commercial and subsistence demand. To the contrary, we found that the local perception was that the ecosystem services from these forests are largely on the decline. We recommend as the next step in this process of assessing forest ecosystem services the quantification of key services, such as timber, fresh water yield, and soil fertility, which could help to identify any causal link between the people's perception and the actual status of the forest ecosystems. Those results should be compared to the expectations defined in the forest management plans and adjustments made in future management activities.

We also recommend educational outreach to villagers about the concept of ecosystem services and their assessment. Given the worldwide focus on this conceptual framework, and Bhutan's efforts to assess the value of ecosystem services nationally, it would be helpful for villagers to understand this way of thinking. 


\section{References}

Baral, H., Jaung, W., Bhatta, L.D., Phuntsho, S., Sharma, S., Paudyal, K., Zarandian, A., Sears, R.R., Sharma, R., Dorji, T., Artati, Y., 2017. Approaches and tools for assessing mountain forest ecosystem services. Center for International Forestry Research (CIFOR), Bogor, Indonesia.

Bathurst, J.C., Iroumé, A., Cisneros, F., Fallas, J., Iturraspe, R., Novillo, M.G., Urciuolo, A., Bièvre, B.d., Borges, V.G., Coello, C., Cisneros, P., Gayoso, J., Miranda, M., Ramírez, M., 2011. Forest impact on floods due to extreme rainfall and snowmelt in four Latin American environments 1: Field data analysis. Journal of Hydrology 400, 281-291. https://doi.org/10.1016/j. jhydrol.2010.11.044.

Bhatta, L.D., van Oort, B.E.H., Stork, N.E., Baral, H., 2015. Ecosystem services and livelihoods in a changing climate: Understanding local adaptations in the Upper Koshi, Nepal. International Journal of Biodiversity Science, Ecosystem Services \& Management 11, 145-155. 10.1080/21513732.2015.1027793.

Brown, G., 2013. The relationship between social values for ecosystem services and global land cover: An empirical analysis. Ecosystem Services 5, 58-68. https://doi.org/10.1016/j.ecoser.2013.06.004.

Brown, G.W., Gahler, A.R., Marston, R.B., 1973. Nutrient losses after clear-cut logging and slash burning in the Oregon Coast Range. Water Resources Research 9, 1450-1453. 10.1029/ WR009i005p01450.

Buffum, B., Gratzer, G., Tenzin, Y., 2008. The sustainability of selection cutting in a late successional broadleaved community forest in Bhutan. Forest Ecology and Management 256, 2084-2091.

Buffum, B., Gratzer, G., Tenzin, Y., 2009. Forest grazing and natural regeneration in a late successional broadleaved community forest in Bhutan. Mountain Research and Development 29, 30-35.

Chen, J., Mroz, G.D., Franklin, J.F., Brosofske, K.D., Saunders, S.C., Crow, T.R., Naiman, R.J., Brookshire, B.L., 1999. Microclimate in Forest Ecosystem and Landscape Ecology: Variations in local climate can be used to monitor and compare the effects of different management regimes. BioScience 49, 288-297. 10.2307/1313612.

Cooper, N., Brady, E., Steen, H., Bryce, R., 2016. Aesthetic and spiritual values of ecosystems: Recognising the ontological and axiological plurality of cultural ecosystem 'services'. Ecosystem Services 21, 218-229. https://doi.org/10.1016/j.ecoser.2016.07.014.

Corbett, E.S., Lynch, J.A., Sopper, W.E., 1978. Timber Harvesting Practices and Water Quality in the Eastern United States. Journal of Forestry 76, 484-488. 10.1093/jof/76.8.484.

Covey, K., Carroll, C.J.W., Duguid, M.C., Dorji, K., Dorji, T., Tashi, S., Wangdi, T., Ashton, M., 2015. Developmental dynamics following selective logging of an evergreen oak forest in the Eastern Himalaya, Bhutan: Structure, composition, and spatial pattern. Forest Ecology and Management 336, 163-173. http://dx.doi.org/10.1016/j.foreco.2014.10.006.

Dan Moore, R., Spittlehouse, D.L., Story, A., 2005. Riparian microclimate and stream temperature response to forest harvesting: A review. JAWRA Journal of the American Water Resources Association 41, 813-834. 10.1111/j.1752-1688.2005.tb03772.x.

Darabant, A., Rai, P.B., Tenzin, K., Roder, W., Gratzer, G., 2007. Cattle grazing facilitates tree regeneration in a conifer forest with palatable bamboo understory. Forest Ecology and Management 252, 73-83.

DoFPS, 2018. Forest Facts and Figures 2017. Department of Forests and Park Services, Ministry of Agriculture and Forests, Royal Government of Bhutan, Thimphu, Bhutan.

FAO, CIFOR, 2005. Forests and Floods: Drowning in fiction or thriving on facts? Center for International Forestry Research and Food and Agricultural Organization, Bogor, Indonesia.

Gilmour, D., 2014. Forests and water: A synthesis of the contemporary science and its relevance for community forestry in the Asia-Pacific region. RECOFT - The Center for People and Forests, Bangkok, Thailand. 
Iniguez-Gallardo, V., Halasa, Z., Briceño, J., 2018. People's Perceptions of Ecosystem Services Provided by Tropical Dry Forests: A Comparative Case Study in Southern Ecuador, in: Sudarshana, P., Nageswara-Rao, M., Soneji, J.R. (Eds.), Tropical Forests IntechOpen.

Kubiszewski, I., Costanza, R., Dorji, L., Thoennes, P., Tshering, K., 2013. An initial estimate of the value of ecosystem services in Bhutan. Ecosystem Services 3, e11-e21. http://dx.doi. org/10.1016/j.ecoser.2012.11.004.

Måren, I.E., Bhattarai, K.R., Chaudhary, R.P., 2014. Forest ecosystem services and biodiversity in contrasting Himalayan forest management systems. Environmental Conservation 41, 73-83. $10.1017 / \mathrm{s} 0376892913000258$.

Martin, C.W., Hornbeck, J.W., 1994. Logging in New England Need Not Cause Sedimentation of Streams. Northern Journal of Applied Forestry 11, 17-23. 10.1093/njaf/11.1.17.

MoAF, 2017. Atlas of Bhutan: Land Use Land Cover 2016, Statistics. Forest Resources Management Division, Department of Forests \& Park Services, Ministry of Agriculture and Forests,, Thimphu, Bhutan.

Moktan, M.R., Gratzer, G., Richards, W.H., Rai, T.B., Dukpa, D., Tenzin, K., 2009. Regeneration of mixed conifer forests under group tree selection harvest management in western Bhutan Himalayas. Forest Ecology and Management 257, 2121-2132.

Morgan, D., 1997. Focus Groups as Qualitative Research, Second ed. Sage, Thousand Oaks, CA.

Paudyal, K., Baral, H., Keenan, R.J., 2016. Local actions for the common good: Can the application of the ecosystem services concept generate improved societal outcomes from natural resource management? Land Use Policy 56, 327-332.

Phuntsho, S., 2015. Community forestry in Bhutan: prospects for replacing the subsidized rural timber supply scheme. Ugyen Wangchuck Institute for Conservation and Environment, Bumthang, Bhutan.

Rai, P.B., Darabant, A., Dorji, T., Sangay, Dukpa, D., Staudhammer, C., Gratzer, G., 2014. Effects of silvicultural openings, livestock grazing, understory competition and microsites on mixed conifer regeneration in western Bhutan. Journal of Renewable Natural Resources Bhutan 10, 146-160.

Rinzin, C., Vermeulen, W.J.V., Wassen, M.J., Glasbergen, P., 2009. Nature conservation and human well-being: an assessment of local community perceptions. Journal of Environment and Development 18, 177-202.

Sagie, H., Morris, A., Rofè, Y., Orenstein, D., Groner, E., 2013. Cross-cultural perceptions of ecosystem services: A social inquiry on both sides of the Israelie Jordanian border of the Southern Arava Valley Desert. Journal of Arid Environments 97, 38-48. 10.1016/j.jaridenv.

Scholte, S.S.K., van Teeffelen, A.J.A., Verburg, P.H., 2015. Integrating socio-cultural perspectives into ecosystem service valuation: A review of concepts and methods. Ecological Economics 114, $67-$ 78. https://doi.org/10.1016/j.ecolecon.2015.03.007.

Sears, R.R., Phuntsho, S., Dorji, T., Choden, K., Norbu, N., Baral, H., 2017. Forest ecosystem services and the pillars of Bhutan's Gross National Happiness. CIFOR Occasional Paper No. 178. http:// dx.doi.org/10.17528/cifor/006631.

Stark, C., 2002. Management plan for the Gidakom Forest Management Unit. Department of Forest and Park Services, Ministry of Agriculture and Forests, Royal Government of Bhutan.

Swinton, S.M., Lupi, F., Robertson, G.P., Hamilton, S.K., 2007. Ecosystem services and agriculture: Cultivating agricultural ecosystems for diverse benefits. Ecological Economics 64.

Terzaghi, E., Wild, E., Zacchello, G., Cerabolini, B.E.L., Jones, K.C., Di Guardo, A., 2013. Forest Filter Effect: Role of leaves in capturing/releasing air particulate matter and its associated PAHs. Atmospheric Environment 74, 378-384. https://doi.org/10.1016/j.atmosenv.2013.04.013.

UWICER, 2018. Factsheet: Implementation of Integrated Watershed Management to Benefit Maximum from Hydro-Power in Bhutan. Ugyen Wangchuck Institute for Conservation and Environmental Research, Royal Government of Bhutan.

Wangdi, T., 2018. Forests Management Plan for the Rongmanchhu Forest Management Unit 20182028. . Department of Forest and Park Services, Ministry of Agriculture and Forests, Royal Government of Bhutan. 
Webb, E., Dorji, L., 2016. The Evolution of Forest- Related Institutions in Bhutan. Asian Instiute of Technology.

WMD, 2017. Drivers of Deforestation and Forest Degradation in Bhutan. DoFPS, MoAF, Thimphu. WWF, 2017. Valuing Ecosystem Services in Chamkharchhu Sub Basin: Mapping sediment using InVEST. World Wildlife Fund for Nature, Thimphu, Bhutan.

Zoderer, B.M., Lupo Stanghellini, P.S., Tasser, E., Walde, J., Wieser, H., Tappeiner, U., 2016.

Exploring socio-cultural values of ecosystem service categories in the Central Alps: the influence of socio-demographic factors and landscape type. Regional Environmental Change 16, 2033 2044. 10.1007/s10113-015-0922-y. 


\section{Appendix}

Priority ES identified, reasons for rankings, trends, reasons for change and opinion for improvement in the study area (Ecosystem services are listed chronologically based on their priority)

\begin{tabular}{|c|c|c|c|c|c|}
\hline $\begin{array}{l}\text { Ecosystem Services } \\
\text { category }\end{array}$ & Ecosystem Services & Reasons & $\begin{array}{c}\text { Trend } \\
(2006-2016)\end{array}$ & Reason for changes & Improvement \\
\hline \multicolumn{6}{|c|}{ Khaling-Kharungla Female Group } \\
\hline Habitat or supporting & Land productivity & $\begin{array}{l}\text { Supports other services, trees, } \\
\text { water, agriculture, stone and } \\
\text { houses are all hold by the land }\end{array}$ & $(-)$ & $\begin{array}{l}\text { Erosion and flood through } \\
\text { construction of road and } \\
\text { other development activities } \\
\text { has decreased the agriculture } \\
\text { products }\end{array}$ & $\begin{array}{l}\text { Land management including } \\
\text { plantation at the eroded areas, } \\
\text { protect from forest fire, reduce } \\
\text { timber extraction }\end{array}$ \\
\hline Provisioning & Freshwater & $\begin{array}{l}\text { Important for preparation of food, } \\
\text { drinking, washing, hygiene and } \\
\text { sanitation. And also, for irrigation, } \\
\text { feeding livestock, spiritual offering, } \\
\text { and hydropower energy }\end{array}$ & $(-)$ & $\begin{array}{l}\text { More timber extraction, } \\
\text { increasing households, } \\
\text { population, and waste disposal at } \\
\text { the source }\end{array}$ & $\begin{array}{l}\text { Plantation of trees like Ficus } \\
\text { sp, Musa sp. Stop supplying } \\
\text { timber to outsiders }\end{array}$ \\
\hline Provisioning & Timber & $\begin{array}{l}\text { Used for house construction, } \\
\text { fuelwood, furniture, fruits, } \\
\text { mushroom, fodder, oxygen, clothes, } \\
\text { paper, and host for silkworms }\end{array}$ & $(-)$ & $\begin{array}{l}\text { Timber species like Michelia } \\
\text { sp. declined due to increasing, } \\
\text { population, soil erosion that } \\
\text { hampers erosion, vehicle } \\
\text { emission and other machineries. } \\
\text { Climate change likely the cause } \\
\text { of vegetation shift. More timber } \\
\text { and fuelwood extraction }\end{array}$ & $\begin{array}{l}\text { Protect the existing trees and } \\
\text { reducing extraction. More } \\
\text { coordination with marking } \\
\text { officials to conserve trees and } \\
\text { water. Stop allotting the timber } \\
\text { to outside contractor/residents }\end{array}$ \\
\hline Regulating & Fresh air & $\begin{array}{l}\text { Important for survival, for } \\
\text { breathing, and growth of trees and } \\
\text { animals }\end{array}$ & 0 & $\begin{array}{l}\text { Increasing population, more } \\
\text { emission, pollution and more } \\
\text { timber extraction }\end{array}$ & $\begin{array}{l}\text { Waste management, avoiding } \\
\text { pollution, conserve forest, } \\
\text { plantation, and regulating } \\
\text { timber extraction }\end{array}$ \\
\hline Provisioning & Stone & $\begin{array}{l}\text { House construction, in contrary } \\
\text { house can be built without } \\
\text { using stone, not very important } \\
\text { compared to other services }\end{array}$ & $(-)$ & $\begin{array}{l}\text { Population increase, road } \\
\text { construction, and transportation } \\
\text { to outside }\end{array}$ & $\begin{array}{l}\text { Stop supplying stone to } \\
\text { outsiders and apprehend } \\
\text { offenders }\end{array}$ \\
\hline
\end{tabular}


Appendix Continued

\begin{tabular}{|c|c|c|c|c|c|}
\hline $\begin{array}{l}\text { Ecosystem Services } \\
\text { category }\end{array}$ & Ecosystem Services & Reasons & $\begin{array}{c}\text { Trend } \\
(2006-2016)\end{array}$ & Reason for changes & Improvement \\
\hline \multicolumn{6}{|c|}{ Kaling-Kharungla Male Group } \\
\hline Habitat or supporting & Land productivity & $\begin{array}{l}\text { Most important phenomenon for } \\
\text { origin of other ES. Agriculture and } \\
\text { forest products }\end{array}$ & $(-)$ & $\begin{array}{l}\text { Increased temperature, less } \\
\text { cattle for manure production, } \\
\text { application chemical fertilizers, } \\
\text { construction of road that diverts } \\
\text { nutrients, and loss of land from } \\
\text { road construction }\end{array}$ & $\begin{array}{l}\text { Preparation of manure, land } \\
\text { management, collection of } \\
\text { leaf litter/leaf mould, establish } \\
\text { agroforestry }\end{array}$ \\
\hline Provisioning & Timber & $\begin{array}{l}\text { Trees generate oxygen for } \\
\text { lives, construction of house and } \\
\text { monuments }\end{array}$ & $(-)$ & $\begin{array}{l}\text { Timber species with clean bole } \\
\text { decreased due to construction of } \\
\text { road, and increased demand for } \\
\text { house construction }\end{array}$ & Plantation and conservation \\
\hline \multirow[t]{2}{*}{ Provisioning } & Freshwater & $\begin{array}{l}\text { Provide drinking water human } \\
\text { and wildlife, health and hygiene, } \\
\text { washing, cooking, irrigation and } \\
\text { cultivation of crops }\end{array}$ & $(-)$ & $\begin{array}{l}\text { Cutting down of trees at the } \\
\text { source, increased surface } \\
\text { water and less recharge, and } \\
\text { construction of logging road }\end{array}$ & $\begin{array}{l}\text { Plantation of trees and fencing } \\
\text { the source }\end{array}$ \\
\hline & Fresh air & $\begin{array}{l}\text { Life supporting element, absorb } \\
\text { carbon, dust and support growth } \\
\text { of trees }\end{array}$ & $(-)$ & $\begin{array}{l}\text { Pollution from vehicle, loss } \\
\text { of forest through logging, } \\
\text { developmental activities and } \\
\text { road construction }\end{array}$ & $\begin{array}{l}\text { Plantation of trees, regulate } \\
\text { the machinery emission, } \\
\text { regulate the excessive emitting } \\
\text { machines and motor vehicles }\end{array}$ \\
\hline Provisioning & Stone & $\begin{array}{l}\text { Reside spirits, local deity, } \\
\text { construction of house, and } \\
\text { construction of wall for land } \\
\text { management }\end{array}$ & $(-)$ & $\begin{array}{l}\text { After construction of road, stone } \\
\text { transported to outsider }\end{array}$ & $\begin{array}{l}\text { Regulate supply of stone to } \\
\text { contractors, and regulate the } \\
\text { issuance of permit to outsiders }\end{array}$ \\
\hline \multicolumn{6}{|c|}{ Lingmethang (Jangdung) Female Group } \\
\hline Habitat or supporting & Land productivity & $\begin{array}{l}\text { Support every living organism, and } \\
\text { provide agriculture fertile land }\end{array}$ & $(++)$ & $\begin{array}{l}\text { More production by applying } \\
\text { FYM and soil fertility is not } \\
\text { degraded yet as the settlement } \\
\text { took about } 15-20 \text { years }\end{array}$ & $\begin{array}{l}\text { Improve by managing land } \\
\text { through construction of } \\
\text { terraces }\end{array}$ \\
\hline Provisioning & Freshwater & $\begin{array}{l}\text { Water for life, sanitation, } \\
\text { agriculture, forest and animals }\end{array}$ & $(-)$ & $\begin{array}{l}\text { Increase in population, more } \\
\text { road construction and extraction } \\
\text { of timber }\end{array}$ & $\begin{array}{l}\text { Improve and protect water } \\
\text { source by fencing }\end{array}$ \\
\hline
\end{tabular}




\section{Appendix Continued}

\begin{tabular}{|c|c|c|c|c|c|}
\hline $\begin{array}{l}\text { Ecosystem Services } \\
\text { category }\end{array}$ & Ecosystem Services & Reasons & $\begin{array}{c}\text { Trend } \\
(2006-2016)\end{array}$ & Reason for changes & Improvement \\
\hline Provisioning & Timber & $\begin{array}{l}\text { Construction of house and } \\
\text { fuelwood }\end{array}$ & $(-)$ & $\begin{array}{l}\text { Decreased due to increased } \\
\text { demand for house construction } \\
\text { and logging activities }\end{array}$ & $\begin{array}{l}\text { Raise native species for } \\
\text { plantation }\end{array}$ \\
\hline Regulating & Fresh air & Sustain all live forms & $(-)$ & $\begin{array}{l}\text { Increasing use of machineries, } \\
\text { vehicles, and increasing } \\
\text { population }\end{array}$ & $\begin{array}{l}\text { Plantation and proper } \\
\text { management of waste }\end{array}$ \\
\hline Regulating & Carbon sequestration & $\begin{array}{l}\text { Regulate the } \mathrm{CO} 2 \text { in the air } \\
\text { and provide fresh air for living } \\
\text { organisms }\end{array}$ & $(-)$ & $\begin{array}{l}\text { Increased population and use of } \\
\text { machineries }\end{array}$ & $\begin{array}{l}\text { Regulate use of machineries } \\
\text { and plant more trees }\end{array}$ \\
\hline \multicolumn{6}{|c|}{ Lingmethang Male Group } \\
\hline Habitat or supporting & Land productivity & $\begin{array}{l}\text { Cultivation of crops, place to live, } \\
\text { habitats for all living organisms, } \\
\text { and source of water }\end{array}$ & $(+)$ & $\begin{array}{l}\text { More modern chemical inputs } \\
\text { used for crop production }\end{array}$ & $\begin{array}{l}\text { Prepare terrace for nutrient } \\
\text { retention }\end{array}$ \\
\hline Provisioning & Freshwater & $\begin{array}{l}\text { Health and hygiene, industries, } \\
\text { drinking }\end{array}$ & $(--)$ & $\begin{array}{l}\text { Increasing population resulted } \\
\text { extraction of water for } \\
\text { Lingmethang town, construction } \\
\text { concrete at the source has } \\
\text { decreased source }\end{array}$ & $\begin{array}{l}\text { Protection and plantation at } \\
\text { the source }\end{array}$ \\
\hline Provisioning & Timber & $\begin{array}{l}\text { Construction of traditional house } \\
\text { and Dzongs; supply of fuelwood } \\
\text { and fodder trees }\end{array}$ & $(-)$ & $\begin{array}{l}\text { Now timber resources pushed } \\
\text { to a distant because of logging } \\
\text { activities, earlier used to be } \\
\text { nearby }\end{array}$ & $\begin{array}{l}\text { Plantation in the timber } \\
\text { extracted area }\end{array}$ \\
\hline Regulating & Fresh air & $\begin{array}{l}\text { Maintain cleanliness, health and } \\
\text { hygiene, and life line for living } \\
\text { animals }\end{array}$ & $(-)$ & $\begin{array}{l}\text { Felling of more trees decreased } \\
\text { oxygen. Now people get cold } \\
\text { and cough and other diseases } \\
\text { very often }\end{array}$ & $\begin{array}{l}\text { Plantation at the source, } \\
\text { reduce the waste, and avoid } \\
\text { burning waste }\end{array}$ \\
\hline Provisioning & Stone & House construction & $(-)$ & $\begin{array}{l}\text { Contract activities and logging } \\
\text { road access decreased quality } \\
\text { and quantity of stone }\end{array}$ & $\begin{array}{l}\text { Restrict the outsiders to } \\
\text { extract from their locality }\end{array}$ \\
\hline
\end{tabular}


Appendix Continued

\begin{tabular}{|c|c|c|c|c|c|}
\hline $\begin{array}{l}\text { Ecosystem Services } \\
\text { category }\end{array}$ & Ecosystem Services & Reasons & $\begin{array}{c}\text { Trend } \\
(2006-2016)\end{array}$ & Reason for changes & Improvement \\
\hline \multicolumn{6}{|c|}{ Rongmanchhu (Kupinelsa/Budhur) Female Group } \\
\hline Habitat or supporting & Land productivity & $\begin{array}{l}\text { Foundation for other services, } \\
\text { main sources for food, trees and } \\
\text { water }\end{array}$ & 0 & $\begin{array}{l}\text { Production remain almost same } \\
\text { in a decade }\end{array}$ & Add leaf mould \\
\hline Provisioning & Timber & $\begin{array}{l}\text { Trees grows on land which links } \\
\text { land productivity, freshwater and } \\
\text { fresh air. Used for construction of } \\
\text { house and other utility }\end{array}$ & $(-)$ & $\begin{array}{l}\text { Increasing population, led more } \\
\text { extraction }\end{array}$ & Plantation and conservation \\
\hline Provisioning & Freshwater & $\begin{array}{l}\text { Supports health and hygiene, } \\
\text { drinking, cooking. Trees help } \\
\text { percolation of water in the ground }\end{array}$ & $(-)$ & $\begin{array}{l}\text { Road construction and timber } \\
\text { extraction }\end{array}$ & $\begin{array}{l}\text { Plantation and forest } \\
\text { protection at the source }\end{array}$ \\
\hline Regulating & Fresh air & $\begin{array}{l}\text { Helps growth of living animals, } \\
\text { breathing, cleanliness, and support } \\
\text { live forms }\end{array}$ & $(-)$ & $\begin{array}{l}\text { Pollution, increasing population } \\
\text { and waste }\end{array}$ & Minimize use of machineries \\
\hline Provisioning & Stone & Construction of house and fencing & $(-)$ & $\begin{array}{l}\text { Timber extracted by outsiders } \\
\text { and NRDCL }\end{array}$ & \\
\hline \multicolumn{6}{|c|}{ Rongmanchhu Male Group } \\
\hline Habitat or supporting & Land productivity & $\begin{array}{l}\text { Land supports other existence and } \\
\text { food production }\end{array}$ & $(-)$ & $\begin{array}{l}\text { Earlier apply leaf mould, now } \\
\text { people apply chemical fertilizer }\end{array}$ & $\begin{array}{l}\text { Apply and use of more organic } \\
\text { manure }\end{array}$ \\
\hline Provisioning & Timber & $\begin{array}{l}\text { House construction, fuelwood, } \\
\text { carbon sequestration, source of } \\
\text { oxygen and water percolation }\end{array}$ & $(-)$ & $\begin{array}{l}\text { Earlier people collect nearby } \\
\text { village, now people have to walk } \\
\text { about a day, more extraction of } \\
\text { timber by NRDCL (Government) } \\
\text { contractors and prime timber are } \\
\text { all logged }\end{array}$ & $\begin{array}{l}\text { Plantation and joint } \\
\text { management with forestry } \\
\text { personnel }\end{array}$ \\
\hline Provisioning & Freshwater & $\begin{array}{l}\text { Growth of plants. Supports health } \\
\text { and hygiene, cooking, and drinking }\end{array}$ & $(-)$ & $\begin{array}{l}\text { Water sources upstream dried } \\
\text { due to felling of trees, quality } \\
\text { has decline due to extraction of } \\
\text { resources and other development } \\
\text { activities }\end{array}$ & $\begin{array}{l}\text { Protect water source. Not } \\
\text { letting cattle at the source. } \\
\text { Protect forest cover at the } \\
\text { source catchment }\end{array}$ \\
\hline Regulating & Fresh air & $\begin{array}{l}\text { Supports lives on earth, provides } \\
\text { clean air and supports health }\end{array}$ & $(-)$ & $\begin{array}{l}\text { Deforestation, air pollution, } \\
\text { forest fire, and of burning waste }\end{array}$ & $\begin{array}{l}\text { Plantation, reduce waste, and } \\
\text { machineries }\end{array}$ \\
\hline
\end{tabular}




\section{Appendix Continued}

\begin{tabular}{|c|c|c|c|c|c|}
\hline $\begin{array}{l}\text { Ecosystem Services } \\
\text { category }\end{array}$ & Ecosystem Services & Reasons & $\begin{array}{c}\text { Trend } \\
(2006-2016)\end{array}$ & Reason for changes & Improvement \\
\hline Provisioning & Stone & $\begin{array}{l}\text { Basis for formation of soil, } \\
\text { house construction, and land } \\
\text { management }\end{array}$ & 0 & $\begin{array}{l}\text { Quality decreased, transported by } \\
\text { the contractors }\end{array}$ & $\begin{array}{l}\text { Restrict outsiders to collect } \\
\text { from their locality }\end{array}$ \\
\hline \multicolumn{6}{|c|}{ Chendebji Female Group } \\
\hline Regulating & Fresh air & $\begin{array}{l}\text { Life supporting, and carbon } \\
\text { sequestration }\end{array}$ & $(-)$ & $\begin{array}{l}\text { More vehicle, more } \\
\text { developmental activities, more } \\
\text { road widening, and more } \\
\text { machine }\end{array}$ & $\begin{array}{l}\text { Sanction vehicle, black } \\
\text { topping of roads, accelerating } \\
\text { the completion of projects } \\
\text { (Nikachhu, and road } \\
\text { widening) }\end{array}$ \\
\hline Habitat or supporting & Land productivity & $\begin{array}{l}\text { Main source of other resources, all } \\
\text { other ecosystem services comes } \\
\text { from the land }\end{array}$ & $(-)$ & $\begin{array}{l}\text { Power transmission line, road } \\
\text { widening, wide area for pastures }\end{array}$ & $\begin{array}{l}\text { Plantation and reduce felling } \\
\text { trees }\end{array}$ \\
\hline \multirow[t]{2}{*}{ Provisioning } & Freshwater & $\begin{array}{l}\text { Life supporting elements. It needs } \\
\text { for all living being for survival, } \\
\text { health and hygiene, for irrigation } \\
\text { and drinking }\end{array}$ & $(++)$ & $\begin{array}{l}\text { Source protection through } \\
\text { government support, water } \\
\text { connection in the settlements }\end{array}$ & Plantation and fencing, \\
\hline & Timber & $\begin{array}{l}\text { House construction, source of } \\
\text { oxygen, flood control, firewood, } \\
\text { furniture, continuous supply of } \\
\text { water, medicinal, raw materials for } \\
\text { clothes, burr, habitat for animals, } \\
\text { and provide shade }\end{array}$ & $(-)$ & $\begin{array}{l}\text { Most matured trees extracted } \\
\text { only young trees are available. } \\
\text { Quantity increased as law limited } \\
\text { felling the trees. More protection }\end{array}$ & $\begin{array}{l}\text { Let the young tree attain } \\
\text { matured }\end{array}$ \\
\hline Provisioning & Stone & $\begin{array}{l}\text { Abundant but important for } \\
\text { house construction, fencing, wall } \\
\text { construction, and soil protection }\end{array}$ & $(-)$ & $\begin{array}{l}\text { More construction activities, } \\
\text { road widening, and illegal } \\
\text { business }\end{array}$ & $\begin{array}{l}\text { Restrict outsider to collect and } \\
\text { sell }\end{array}$ \\
\hline
\end{tabular}

continued on next page 
Appendix Continued

\begin{tabular}{|c|c|c|c|c|c|}
\hline $\begin{array}{l}\text { Ecosystem Services } \\
\text { category }\end{array}$ & Ecosystem Services & Reasons & $\begin{array}{c}\text { Trend } \\
\text { (2006-2016) }\end{array}$ & Reason for changes & Improvement \\
\hline Habitat or supporting & Land productivity & $\begin{array}{l}\text { Main foundation for other } \\
\text { ecosystem and supports living } \\
\text { organism }\end{array}$ & $(-)$ & $\begin{array}{l}\text { Cultivated land decreased, forest } \\
\text { land improved. Now people } \\
\text { apply fertilizer from the market. } \\
\text { Less belief on birth spirits, no } \\
\text { offerings done by the younger } \\
\text { generations, and cultural values } \\
\text { degrading. In the past set forest } \\
\text { fire for crop production and now } \\
\text { its restricted }\end{array}$ & $\begin{array}{l}\text { Raise cow for production } \\
\text { of organic manure, timely } \\
\text { offering to the spirits. Prepare } \\
\text { FYM for improving soil } \\
\text { fertility }\end{array}$ \\
\hline Provisioning & Freshwater & $\begin{array}{l}\text { Indispensable life supporting } \\
\text { element. Without water there is no } \\
\text { other life forms }\end{array}$ & $(-)$ & $\begin{array}{l}\text { Increase population and water } \\
\text { use, and more disturbances to the } \\
\text { forest }\end{array}$ & $\begin{array}{l}\text { Protect forest and water } \\
\text { sources }\end{array}$ \\
\hline Provisioning & Timber & $\begin{array}{l}\text { Furniture and timber, source of } \\
\text { oxygen, agriculture implements, } \\
\text { protection of flood, and } \\
\text { maintenance of soil fertility }\end{array}$ & $(-)$ & $\begin{array}{l}\text { In the past people collect from } \\
\text { the distant and now they collect } \\
\text { nearby the village even the } \\
\text { young trees for constructions. } \\
\text { Matured trees have gone down, } \\
\text { as it is harvested }\end{array}$ & $\begin{array}{l}\text { Establishment of the } \\
\text { community forest and restrict } \\
\text { the harvesting, and prepare } \\
\text { the proper management plan. } \\
\text { Restrict the timber supply in } \\
\text { the other residents outside the } \\
\text { FMU areas }\end{array}$ \\
\hline
\end{tabular}


Appendix Continued

\begin{tabular}{|c|c|c|c|c|c|}
\hline $\begin{array}{l}\text { Ecosystem Services } \\
\text { category }\end{array}$ & Ecosystem Services & Reasons & $\begin{array}{c}\text { Trend } \\
(2006-2016)\end{array}$ & Reason for changes & Improvement \\
\hline Cultural & $\begin{array}{l}\text { Birth and guardian } \\
\text { deity }\end{array}$ & $\begin{array}{l}\text { Give lives for survival, peace and } \\
\text { protect from the evil spirits }\end{array}$ & $(++)$ & $\begin{array}{l}\text { All time believers cause no } \\
\text { harm, if all can worship and } \\
\text { offer timely, protection from } \\
\text { evil spirits are secures, thus in a } \\
\text { way vegetation improves at the } \\
\text { site which helps in protection of } \\
\text { resources }\end{array}$ & $\begin{array}{l}\text { Continue with the current } \\
\text { practice and pass to } \\
\text { generations }\end{array}$ \\
\hline \multicolumn{6}{|c|}{ Kekhar Female group } \\
\hline Habitat or supporting & Land productivity & $\begin{array}{l}\text { Main base for the living being on } \\
\text { earth }\end{array}$ & $(-)$ & $\begin{array}{l}\text { Climate change, increase in use } \\
\text { of machinery and temperature } \\
\text { raise }\end{array}$ & $\begin{array}{l}\text { Protect forest, and use of } \\
\text { organic/leaf mould }\end{array}$ \\
\hline \multirow[t]{2}{*}{ Provisioning } & Freshwater & $\begin{array}{l}\text { Water important for drinking, } \\
\text { health, hygiene, and irrigation. It is } \\
\text { needed by all living organisms }\end{array}$ & $(-)$ & $\begin{array}{l}\text { Increasing population and } \\
\text { households led to declining } \\
\text { forests }\end{array}$ & $\begin{array}{l}\text { Plantation and protection of } \\
\text { trees at the water source }\end{array}$ \\
\hline & Timber & $\begin{array}{l}\text { Trees growth is supported by } \\
\text { land and needs water to grow. } \\
\text { Important sources for food and } \\
\text { shelter for all living organism }\end{array}$ & $(--)$ & $\begin{array}{l}\text { Logging by NRDCL as all } \\
\text { matured tress are extracted, } \\
\text { seedlings are not regenerating } \\
\text { after harvest, increasing demand } \\
\text { due to population rise, both from } \\
\text { the locality and village }\end{array}$ & Protect trees and plantation \\
\hline Regulating & Fresh air & $\begin{array}{l}\text { Life supporting element, and } \\
\text { sequester the carbon }\end{array}$ & $(-)$ & $\begin{array}{l}\text { Decline in trees, crop production } \\
\text { expected to decline, disease } \\
\text { outbreak both in crops and } \\
\text { people }\end{array}$ & $\begin{array}{l}\text { Protect trees and reduce use of } \\
\text { machineries }\end{array}$ \\
\hline Regulating & Pollination & $\begin{array}{l}\text { Maintain continuity of the } \\
\text { resources. As local peoples quoted } \\
\text { "No people, empty village, no } \\
\text { bird, empty valley, no trees, empty } \\
\text { forest" thus pollination makes } \\
\text { possible on continuity of genetic } \\
\text { resources and fill the emptiness }\end{array}$ & $(-)$ & $\begin{array}{l}\text { More forest harvested, increasing } \\
\text { population, sustainability of the } \\
\text { genetic resources endangered } \\
\text { through timber extraction }\end{array}$ & $\begin{array}{l}\text { Limit the extraction of timber, } \\
\text { raise the bees, and protect } \\
\text { the wild animals to help } \\
\text { pollination }\end{array}$ \\
\hline
\end{tabular}


Appendix Continued

\begin{tabular}{|c|c|c|c|c|c|}
\hline $\begin{array}{l}\text { Ecosystem Services } \\
\text { category }\end{array}$ & Ecosystem Services & Reasons & $\begin{array}{c}\text { Trend } \\
(2006-2016)\end{array}$ & Reason for changes & Improvement \\
\hline \multicolumn{6}{|c|}{ Kekhar Male Group } \\
\hline Habitat or supporting & Land productivity & $\begin{array}{l}\text { Cultivation, building house, all } \\
\text { other services take place on land } \\
\text { thus serves foundation for other } \\
\text { services }\end{array}$ & $(-)$ & $\begin{array}{l}\text { Depends on the way people put } \\
\text { effort for cultivation, production } \\
\text { gone down, in the past manures } \\
\text { are not required, now have } \\
\text { to apply manure for crop } \\
\text { production because of nutrient } \\
\text { depletion and climate change }\end{array}$ & $\begin{array}{l}\text { Raise livestock and prepare } \\
\text { FYM, leave land fellow for } \\
\text { few years to regain fertility, } \\
\text { incorporate multicultivation, } \\
\text { cultivate nitrogen fixing crops- } \\
\text { legumes (soybean, beans, } \\
\text { barley, millet), collect leaf } \\
\text { mould and litter, introduce } \\
\text { land management and } \\
\text { refrain from use of chemical } \\
\text { fertilizers }\end{array}$ \\
\hline Provisioning & Freshwater & $\begin{array}{l}\text { Water is life supporting for } \\
\text { wild animals, plants, irrigation, } \\
\text { vegetable, health, sanitation and } \\
\text { hydropower energy }\end{array}$ & $(-)$ & $\begin{array}{l}\text { Quantity gone has down, harvest } \\
\text { of trees at the proximity to } \\
\text { sources, climate change, and } \\
\text { no awareness from the concern } \\
\text { agencies }\end{array}$ & $\begin{array}{l}\text { Protect and conserve the trees, } \\
\text { plant trees that also serves } \\
\text { live fencing, not allowing } \\
\text { to extract timber and other } \\
\text { resources, create awareness to } \\
\text { the public by how to retain the } \\
\text { water discharge }\end{array}$ \\
\hline Provisioning & Timber & $\begin{array}{l}\text { House construction, water } \\
\text { production, firewood, oxygen, } \\
\text { flood control, fruits, water } \\
\text { treatment, provide shade, } \\
\text { manures, wood and art craft, job } \\
\text { opportunities, furniture, paper } \\
\text { production, and medicinal plants }\end{array}$ & $(-)$ & $\begin{array}{l}\text { All accessible area the timber } \\
\text { has gone down, non-accessible } \\
\text { areas has more trees. In the } \\
\text { past lots of trees extracted } \\
\text { for construction of Dzong/ } \\
\text { Lhakhang/towns. People have no } \\
\text { authority to control/restrict, and } \\
\text { more demand for timber due to } \\
\text { increase in population. Matured } \\
\text { trees for timber gone down. } \\
\text { Mother trees are extracted and } \\
\text { no seed for seedling }\end{array}$ & $\begin{array}{l}\text { Plant trees, regulate supply to } \\
\text { outsiders }\end{array}$ \\
\hline
\end{tabular}




\section{Appendix Continued}

\begin{tabular}{|c|c|c|c|c|c|}
\hline $\begin{array}{l}\text { Ecosystem Services } \\
\text { category }\end{array}$ & Ecosystem Services & Reasons & $\begin{array}{c}\text { Trend } \\
(2006-2016)\end{array}$ & Reason for changes & Improvement \\
\hline Regulating & Fresh air & $\begin{array}{l}\text { Oxygen generate by trees, that } \\
\text { are crucial for energy, for making } \\
\text { fire, survival, health and hygiene, } \\
\text { dispersal of seeds/pollen grains, } \\
\text { and energy for power }\end{array}$ & 0 & $\begin{array}{l}\text { No adverse diseases occurred } \\
\text { within } 10 \text { years' time on the } \\
\text { livelihood of the people in the } \\
\text { village. }\end{array}$ & $\begin{array}{l}\text { Restrict construction of } \\
\text { industries, proper management } \\
\text { of waste, sustainable } \\
\text { harvesting of trees, recycle the } \\
\text { non-degradable waste, reduce } \\
\text { the use of machineries, and } \\
\text { impose green tax }\end{array}$ \\
\hline Regulating & $\begin{array}{l}\text { Local weather } \\
\text { regulation }\end{array}$ & $\begin{array}{l}\text { Place at the last because of the } \\
\text { more forest covers, as we do not } \\
\text { have issues like other countries. } \\
\text { Seasonal regulation helps timely } \\
\text { activities in village. Industries, } \\
\text { vehicles are not much as that of } \\
\text { neighboring countries, China } \\
\text { and India, no impact on weather } \\
\text { change, thus it places in the last. }\end{array}$ & $(-)$ & $\begin{array}{l}\text { Untimely rain, for irrigation in } \\
\text { the past locality get rain during } \\
\text { the } 4 \text { th month of Bhutanese } \\
\text { calendar while today rain is } \\
\text { expected only by 6th month of } \\
\text { Bhutanese calendar, thus crop } \\
\text { productivity is hampered }\end{array}$ & $\begin{array}{l}\text { Conservation of forest and } \\
\text { water, and reduce use of } \\
\text { carbon emitting machineries }\end{array}$ \\
\hline
\end{tabular}





\section{DOI: $10.17528 /$ cifor $/ 007327$}

CIFOR Working Papers contain preliminary or advance research results on tropical forest issues that need to be published in a timely manner to inform and promote discussion. This content has been internally reviewed but has not undergone external peer review.

Forest Management Units (FMU) are areas of state forest that are designated for commercial timber harvest. They also serve subsistence needs for neighboring villages, but there has to date been no assessment of these services for local people. Neither has there been a formal assessment of the impacts of timber harvest on the ecosystem services. Using a participatory research approach of focus group discussion, we aimed to identify local community perceptions of the priority ecosystem services from FMU forests and to assess the perceived changes of these services after forestry operations. We conducted focus groups segregated by gender with members from eight villages associated with five FMUs in eastern and central Bhutan. The priority services identified by communities, in their own terms, included land productivity, fresh water, timber, fresh air, stone, carbon sequestration, spiritual and religious value, pollination, and local weather regulation. There were minor variations in prioritization of different services across communities and gender groups within communities. Local communities perceived that the ecosystem services provided by the forests within the designated FMU areas have declined over the period of 2006-2016. Community members expressed concern that the decline resulted mainly from excessive extraction of timber and water resources, and reduction of natural regeneration, particularly on broadleaf forests. Therefore, we identify a need for biophysical studies to seek evidence for causal linkages between the manners of natural resource use and the status of ecosystem services. This will fill the knowledge gap between perceived and actual changes that could then drive changes in forest policy and forest management to improve forest management systems. Until then, the conclusions from this study suggest that people depend on a diversity of services from forests that they have access to but do not govern.

\begin{tabular}{|c|c|c|}
\hline 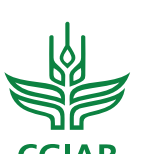 & $\begin{array}{l}\text { RESEARCH } \\
\text { PROGRAM ON } \\
\text { Forests, Trees and } \\
\text { Agroforestry }\end{array}$ & $\begin{array}{l}\text { The CGIAR Research Program on Forests, Trees and Agroforestry (FTA) is the world's largest } \\
\text { research for development program to enhance the role of forests, trees and agroforestry in } \\
\text { sustainable development and food security and to address climate change. CIFOR leads FTA } \\
\text { in partnership with Bioversity International, CATIE, CIRAD, ICRAF, INBAR and TBI. }\end{array}$ \\
\hline & & FTA's research is supported by CGIAR Fund Donors: cgiar.org/funders/ \\
\hline
\end{tabular}

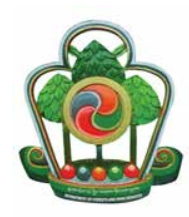

Austrian

Development Agency

\section{cifor.org | forestsnews.cifor.org}

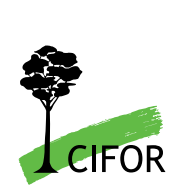

Center for International Forestry Research (CIFOR)

CIFOR advances human well-being, equity and environmental integrity by conducting innovative research, developing partners' capacity, and actively engaging in dialogue with all stakeholders to inform policies and practices that affect forests and people. CIFOR is a CGIAR Research Center, and leads the CGIAR Research Program on Forests, Trees and Agroforestry (FTA). Our headquarters are in Bogor, Indonesia, with offices in Nairobi, Kenya; Yaounde, Cameroon; Lima, Peru and Bonn, Germany.



